\title{
A LETTER FROM THE CENTRE
}

One night in 1977, when Ronald Robinson was visiting Leiden, our discussion came to focus on the teaching of European expansion in the university curriculum. "Robbie" said he thought it dated from just after the war, at Cambridge. George Winius said he thought it was much older, from between the World Wars, when it had been taught at Columbia University in New York. The question remained open, however, for six years, or until Professor Graham Irwin, of Columbia, wrote us about some other matter and happened to mention that he was currently teaching the course. Remembering the 1977 discussion, we immediately wrote him back and asked him to check into the Columbia University tradition and write an article for us. He kindly did so - and we have finally run the whole intellectual problem of the concept of European expansion to earth - where it originated and where and under what circumstances it first was taught. Like Robbie, Professor Irwin is an Englishman, but his conclusions will surprise you.

The article by Martin Klein also requires some brief explanation: it is based on his paper, read last year in Budapest and it may seem rather specialized on first glance. But it describes a process which has many analogies in other parts of the colonial world. Maybe some of you in our audience would like to follow up its ideas by writing articles of your own for us.

Norman Etherington's article flows out of our last issue, and we think you will agree that it is a very useful one. And, finally, while we have no specific archival article in this issue, the articles by Robert Cribb and Om Prakash describe specific archival and research problems, which have a more general applicability than many a description of an archive.

Nor, for that matter, does the interview with Father António da Silva Rego stray far from the archival subject: no man in recent decades has brought more documents from oak gall script to printer's ink and hence into libraries the world over. Almost the whole of George Winius' "Shadow Empire" article on Bengal was written from the documents Silva Rego or his staff have assembled and published. 
The work of the Centre procedes apace. The two volumes of Intercontinenta which were announced in a flyer in the last number of this journal, H.L.M. Obdeyn, The Political Role of the Protestant and Catholic Missions in the Colonial Partition of Black Africa: A Bibliographical Essay and J.A. de Moor, Indisch Militair Tijdschrift: A Selective and Annotated Bibliography, 1870-1942, have now been published, and are available from the Centre. Taco de Bruin is currently engaged in a follow-up to De Moor's work, on the Orgaan der Nederlands-Indische Officierenvereeniging, and discussion of this work is to be found below. Furthermore, the next volume of Comparative Studies in Overseas History, Robert Ross and Gerard J. Telkamp (eds), Colonial Cities, is in the last stages of production, and should be published early in the New Year. By this time, too, the next number of the current Annotated Bibliography of Dutch Expansion Studies will have appeared, as Itinerario (1983) 3/4, after a hiatus of three years caused by the departure of Gerard Telkamp and the difficulties of appointing a successor.

On 21 and 22 June 1984, the Centre intends to hold a Workshop on "Colonial Wars in Africa and Asia, 1870-1914". In addition to general surveys of the theme, and of the relation between what was going on in the conquest of the colonies and in Europe, we hope that case studies on the Maghreb, West Africa, Ethiopia, East Africa, India, Indochina and Indonesia will be presented. 